\title{
Methicillin-resistant Staphylococcus aureus in a Canadian intensive care unit: Delays in initiating effective therapy due to the low prevalence of infection
}

\author{
Wendy Sligl BSc MD FRCPC FACP ${ }^{1,2}$, Geoffrey Taylor BSc MD FRCPC FACP ${ }^{1}$, RT Noel Gibney MB FRCPC ${ }^{2}$, \\ Robert Rennie PhD FCCM D(ABMM) ${ }^{3}$, Linda Chui BSc MSc PhD ${ }^{4}$
}

\begin{abstract}
W Sligl, G Taylor, RTN Gibney, R Rennie, L Chui. Methicillinresistant Staphylococcus aureus in a Canadian intensive care unit: Delays in initiating effective therapy due to the low prevalence of infection. Can J Infect Dis Med Microbiol $2007 ; 18(2): 139-143$.
\end{abstract}

INTRODUCTION: Methicillin-resistant Staphylococcus aureus (MRSA) infection in intensive care units (ICUs) has increased dramatically in prevalence in recent years, and is associated with increased morbidity, mortality and cost of care. The aim of the present study was to describe the epidemiology and outcomes of MRSA infection in the general systems ICU at the University of Alberta Hospital in Edmonton, Alberta.

METHODS: A retrospective cohort analysis of patients infected with MRSA in a general systems ICU was conducted from January 1, 1997, to August 15, 2005.

RESULTS: Forty-six cases of MRSA were identified, of which $36(78.3 \%)$ were infected. The most common admitting diagnoses included respiratory failure $(41.7 \%)$ and sepsis or septic shock $(36.1 \%)$. Infection was hospital acquired in $58.3 \%$ of cases (10 cases ICU acquired), with a median time to infection of 11 days. The most common sites of infection were the respiratory tract, skin and blood. Median lengths of stay were 13 days in the unit and 27 days in-hospital. Crude mortality was $55.6 \%$. Time to appropriate antimicrobial treatment was delayed in $80.5 \%$ of patients. Four prototypical Canadian MRSA (CMRSA) strains were identified by pulsed-field gel electrophoresis. Hospital-acquired strains were predominantly CMRSA-2 $(59 \%)$, indicating that this clone circulates at the University of Alberta Hospital.

CONCLUSIONS: MRSA infection remains uncommon at the University of Alberta Hospital, resulting in delays in instituting appropriate antimicrobial therapy. To date, only a few communityacquired strains have been noted. ICU acquisition of MRSA remains rare, with only 10 cases over the past nine years. The majority of hospital-acquired strains were CMRSA-2.

\section{Staphylocoque doré méthicillinorésistant dans une unité de soins intensifs canadienne : Instauration du traitement efficace retardée par la faible prévalence de l'infection}

INTRODUCTION : La prévalence des infections à staphylocoque doré méthicillinorésistant (ou MRSA, pour methicillin-resistant Staphylococcus aureus) dans les unités de soins intensifs (USI) a considérablement augmenté depuis quelques années et elle est associée à une hausse de la morbidité, de la mortalité et du coût des soins de santé. Le but de l'étude était de décrire l'infection à MRSA dans les USI de soins généraux du University of Alberta Hospital à Edmonton en Alberta du point de vue de son épidémiologie et de son aboutissement.

MÉTHODES : Une analyse de cohorte rétrospective des patients infectés par MRSA dans les USI de soins généraux a été réalisée entre le $1^{\text {er }}$ janvier 1997 et le 15 août 2005.

RÉSULTATS : Quarante-six cas de MRSA ont été identifiés, dont $36(78,3 \%)$ cas d'infection. Les diagnostics les plus fréquents à l'admission étaient insuffisance respiratoire $(41,7 \%)$ et sepsie ou choc septique (36,1\%). L'infection était nosocomiale dans 58,3\% des cas (10 cas ont été transmis dans l'USI) avec un temps médian de 11 jours avant l'infection. Les foyers infectieux les plus courants étaient les voies respiratoires, la peau et le sang. Les séjours médians étaient de 13 jours à l'USI et de 27 jours à l'hôpital. Le taux brut de mortalité était de 55,6 \%. L'intervalle avant l'antibiothérapie appropriée a été retardé chez $80,5 \%$ des patients. Quatre souches prototypes du MRSA canadien (C-MRSA) ont été identifiées par électrophorèse sur gel en champ pulsé. Les souches nosocomiales étaient principalement CMRSA-2 (59\%), indiquant que ce clone circule au University of Alberta Hospital.

CONCLUSION : L'infection à MRSA reste peu fréquente au University of Alberta Hospital, ce qui occasionne un retard dans l'instauration de l'antibiothérapie qui s'impose. À ce jour, seules quelques souches acquises dans la communauté ont été recensées. La transmission du MRSA dans les USI reste rare, soit seulement dix cas au cours des neuf dernières années. La majorité des souches nosocomiales était de type CMRSA-2.

Key Words: Critical care; Intensive care; Methicillin resistance; MRSA; Nosocomial infection; Staphylococcus aureus

\footnotetext{
${ }^{1}$ Division of Infectious Diseases; ${ }^{2}$ Division of Critical Care, University of Alberta; ${ }^{3}$ Division of Medical Microbiology; ${ }^{4}$ University of Alberta Hospital Provincial Laboratory, Edmonton, Alberta

Correspondence: Dr Wendy Sligl, Division of Infectious Diseases, University of Alberta, WMC 2E4.16, 8440-112 Street, Edmonton, Alberta

T6G 2B7. Telephone 780-407-8035, fax 780-407-7137, e-mail wsligl@ualberta.ca

Received for publication October 16, 2006. Accepted January 18, 2007
} 
$\mathrm{M}$ ethicillin-resistant Staphylococcus aureus (MRSA) is responsible for a growing number of nosocomial infections, particularly in the critically ill (1-3). Data from the 2003 National Nosocomial Infections Surveillance System demonstrate higher rates of MRSA in intensive care unit (ICU) patients than in other patient populations (4). Outbreaks have been described globally in adult, pediatric and neonatal ICUs (5-7).

Multiple studies have shown increased morbidity and mortality due to MRSA infection compared with methicillinsusceptible $S$ aureus infection in critically ill patients. MRSA has been shown to prolong ICU stays and lengths of hospital stay, and to result in higher adverse outcomes and costs (8-10).

Clinically and genetically distinct community-acquired MRSA (CA-MRSA) strains have been recently described; these strains, in particular, have resulted in severe disease requiring ICU support (11-13). There is considerable potential for the spread of these strains in the future, as patients lack traditional risk factors and may not meet criteria for screening and/or pre-emptive isolation on admission. The incidence of such strains within Canadian ICUs is unknown.

We undertook the present study to provide epidemiological data, describe outcomes, and examine antimicrobial susceptibility patterns and molecular characteristics of MRSA infection in our general systems ICU at the University of Alberta Hospital (Edmonton, Alberta). We were specifically interested in the extent of nosocomial transmission within our unit, and the presence of community-acquired isolates.

\section{METHODS}

The University of Alberta Hospital is a 700-bed tertiary referral hospital and is the principal teaching hospital of the University of Alberta's Faculty of Medicine. It includes a 30-bed general systems ICU that admits adult general medical, trauma and surgical patients, as well as solid organ transplant recipients.

Inpatient populations have been prospectively surveyed for nosocomial and antibiotic-resistant microorganisms since 1986 as part of routine infection control surveillance. Clinical specimens are processed and analyzed by the clinical microbiology laboratory. ICU patients with MRSA isolates are reviewed by infection control practitioners and are subcategorized as colonized or infected based on United States Centers for Disease Control and Prevention criteria (14).

All ICU patients in whom MRSA was isolated from January 1, 1997, to August 15, 2005, were retrospectively reviewed. Clinical specimens were collected in the setting of suspected infection, and screening was performed on admission to the ICU in patients transferred from other hospitals or health care institutions. Routine MRSA screening for all patients on admission to the unit was not practiced at the time of the study.

Demographic data, time from admission to the development of infection, antimicrobial susceptibilities, choice and timing of empirical antibiotic therapy, ICU length of stay and crude mortality rates were collected. Effective antimicrobial therapy was defined as the initiation of an antimicrobial with in vitro activity against MRSA.

$S$ aureus isolates at the University of Alberta Hospital were identified by routine laboratory procedures. Susceptibility assays performed using BD Phoenix instrumentation (Becton, Dickinson and Company, USA). Methicillin resistance was determined according to Clinical and Laboratory Standards Institute guidelines (15) using a cefoxitin disk diffusion screening test. Isolates

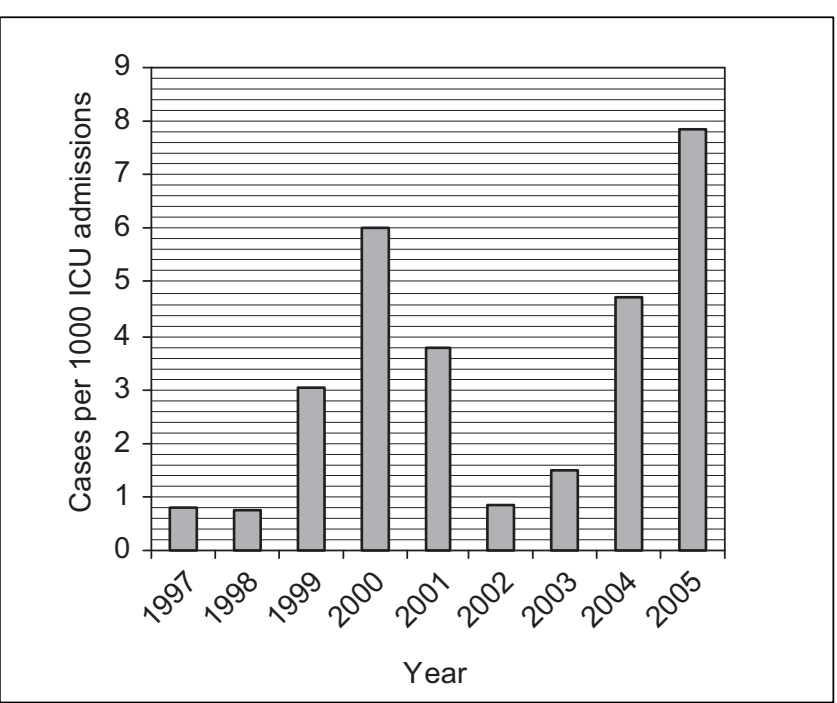

Figure 1) Annual methicillin-resistant Staphylococcus aureus infection rates. ICU Intensive care unit

were further characterized by the detection of the penicillin binding protein (PBP2') using the PBP2' latex agglutination test (MRSA-Screen, Denka Seiken Co, Ltd, Japan). Any S aureus isolate exhibiting cefoxitin resistance and $\mathrm{PBP2}$ ' positivity was considered to be MRSA. In cases in which PBP2' was indeterminate or weakly positive, identification of the mecA gene was performed using polymerase chain reaction (PCR) technology. Staphylococcal chromosomal cassette subtypes and the PantonValentine leukocidin toxin gene were similarly detected using PCR techniques.

Molecular typing by pulsed-field gel electrophoresis (PFGE) to generate macrorestriction fragment length polymorphism patterns was performed on all of the isolates. The protocol was carried out according to a previously described standardized protocol (16). The restricted DNA fragments were resolved by electrophoresis and were analyzed. A relatedness dendrogram was generated using the Dice coefficient with $1 \%$ tolerance and was interpreted according to Tenover's criteria along with previously collected epidemiological data (17). PFGE nomenclature of MRSA strains used by the Canadian Nosocomial Infection Surveillance Program at the National Microbiology Laboratory in Winnipeg, Manitoba, was adopted (18).

MRSA strains were defined as community acquired if they were present or incubating at the time of admission to hospital (identified within $48 \mathrm{~h}$ of admission). Health care-associated strains included those acquired at the hospital, as well as those isolated in patients admitted from long-term care facilities or other hospitals. Based on molecular typing results, specific Canadian MRSA (CMRSA) strains - CMRSA-7 and CMRSA-10 - were also considered to be community acquired.

\section{RESULTS}

There were 11,481 admissions to the general systems ICU from January 1, 1997 to August 15, 2005. Forty-six patients had MRSA isolated from a clinical specimen during their ICU stay. Thirty-six patients $(78.3 \%)$ were infected. The overall infection rate was 3.1 per 1000 ICU admissions, and annual infection rates ranged from 0.7 to 7.8 per 1000 ICU admissions (Figure 1). Of all S aureus isolates from the ICU, approximately 
TABLE 1

Infected subgroup characteristics $(n=36)$

\begin{tabular}{|c|c|}
\hline Mean age, years (range) & $62.5(19$ to 88$)$ \\
\hline Male sex, \% & 72.2 \\
\hline \multicolumn{2}{|l|}{ Comorbidities, n (\%) } \\
\hline Malignancy & $5(14)$ \\
\hline Diabetes (requiring insulin therapy) & $4(11)$ \\
\hline Renal dysfunction* & $4(11)$ \\
\hline Hepatic dysfunction $^{\dagger}$ & $2(6)$ \\
\hline Chronic corticosteroid use ${ }^{\ddagger}$ & $2(6)$ \\
\hline Transplantation & $2(6)$ \\
\hline Neutropenia§ & $1(3)$ \\
\hline HIV infection & $0(0)$ \\
\hline \multicolumn{2}{|l|}{ Admitting diagnoses, $\mathrm{n}(\%)$} \\
\hline Respiratory failure & $15(41.7)$ \\
\hline Sepsis or septic shock & $13(36.1)$ \\
\hline Trauma & $2(5.6)$ \\
\hline Cardiac arrest & $2(5.6)$ \\
\hline Liver failure & $2(5.6)$ \\
\hline Postoperative monitoring & $1(2.8)$ \\
\hline Cerebrovascular accident & $1(2.8)$ \\
\hline Mechanically ventilated, $\mathrm{n}(\%)$ & $35(97)$ \\
\hline Median time to infection, days $(95 \% \mathrm{Cl})$ & 11 (13.1 to 27.6$)$ \\
\hline Total number of infections, $\mathrm{n}(\%)$ & $36(100)$ \\
\hline Health care-associated infections & $34(94.4)$ \\
\hline Acquired at the University of Alberta Hospital & $21(58.3)$ \\
\hline Acquired in the intensive care unit & $10(27.8)$ \\
\hline Acquired outside of the University of Alberta Hospital & $13(36.1)$ \\
\hline Community-acquired infections & $2(5.6)$ \\
\hline Number of infected patients that received therapy, $\mathrm{n}(\%)$ & $33(91.7)$ \\
\hline \multicolumn{2}{|l|}{ Time to initiation of effective therapy } \\
\hline$<24 \mathrm{~h} \pi$ & $4(11.1)$ \\
\hline $24 \mathrm{~h}$ to $72 \mathrm{~h}$ & $15(41.7)$ \\
\hline$>72 \mathrm{~h}$ & $14(38.9)$ \\
\hline \multicolumn{2}{|l|}{ Antimicrobial used } \\
\hline Vancomycin & $31(86.1)$ \\
\hline Trimethoprim-sulfamethoxazole & $2(5.6)$ \\
\hline \multicolumn{2}{|l|}{ Outcomes } \\
\hline Crude mortality rate in infected patients, $\%$ & 55.6 \\
\hline \multicolumn{2}{|l|}{ Median length of stay, days $(95 \% \mathrm{Cl})$} \\
\hline In the intensive care unit & $13(12.9$ to 23.8$)$ \\
\hline In the University of Alberta Hospital & 27 (30.0 to 46.6$)$ \\
\hline
\end{tabular}

${ }^{*}$ Defined as a creatinine level of at least $200 \mu \mathrm{mol} / \mathrm{L}$, or the need for peritoneal dialysis or hemodialysis; ' ${ }^{\dagger}$ Defined as at least two of the following: a bilirubin concentration of at least $40 \mu \mathrm{mol} / \mathrm{L}$, or aspartate aminotransferase or alanine aminotransferase levels more than two times the upper limit of normal;

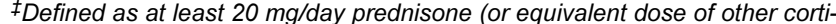
costeroid) for two weeks in the 30 days before admission; ${ }^{\circledR}$ Defined as less than or equal to $500 \times 10^{6} / \mathrm{L}$; $\pi_{T w}$ of the four patients were known to be methicillin-resistant Staphylococcus aureus positive on transfer to the unit

4\% were MRSA from 1997 to 2005, with annual rates ranging from $2 \%$ to $14 \%$.

Characteristics, admitting diagnoses, times to infection and modes of acquisition (health care-associated versus community) in the infected subgroup are presented in Table 1. There was one site of infection in 29 patients $(80.6 \%)$ and two sites in seven patients $(19.4 \%)$. There were 24 respiratory infections, one surgical site infection, one bacteremia infection and three skin infections.

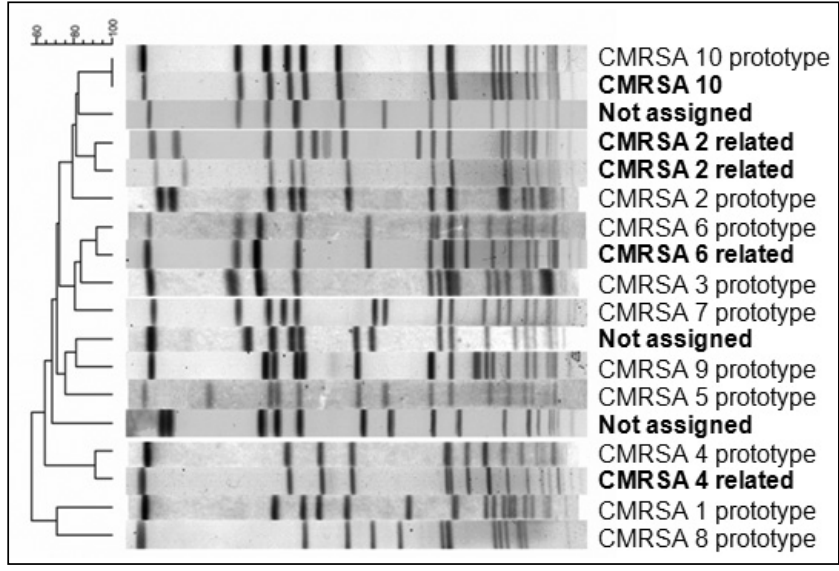

Figure 2) Pulsed-field gel electrophoresis demonstrating the clones identified in the intensive care unit (shown in bold). Four Canadian methicillin-resistant Staphylococcus aureus (CMRSA) clones and three nonassigned clones were identified. All 10 CMRSA prototypes are also shown for comparison

Data on times to treatment with an antimicrobial effective against MRSA after collection of the clinical specimen in suspected infection, types of antimicrobial used, and outcomes are presented in Table 1. Two patients were not treated. The median time to the initiation of appropriate antibiotic therapy was four days. The median length of stay in the unit was 13 days (95\% CI 12.9 to 23.8 days), which was substantially longer than that observed for all-comers to the unit from 1997 to 2005 (median 6.06 days, 95\% CI 5.69 to 6.44 days). The crude mortality rate of $55.6 \%$ compares with an overall mortality rate of $13.6 \%$ in the ICU study patients (2005 data; mortality rates over the entire study period were not available). There were no differences in mortality based on the timing of appropriate antimicrobial therapy, although the numbers were too small for statistical comparison.

Antimicrobial susceptibilities were available for 45 of 46 strains (98\%). All strains were resistant to cefazolin, cloxacillin, erythromycin and penicillin. Three isolates (7\%) were susceptible to clindamycin and 39 (87\%) were susceptible to trimethoprim-sulfamethoxazole. All strains were sensitive to vancomycin, with minimum inhibitory concentrations (MICs) of $2 \mathrm{mg} / \mathrm{L}$ or under in 35 isolates; one isolate had an MIC of $4 \mathrm{mg} / \mathrm{L}$.

PFGE, as shown in Figure 2, revealed four prototypic clones: CMRSA-2, CMRSA-4, CMRSA-6 and CMRSA-10 (19-21). Three additional clones not belonging to the CMRSA prototypes were identified and are denoted 'not assigned'. The isolates acquired at the hospital were predominantly CMRSA-2, which accounted for $59 \%$ of the total. Only one CMRSA-10 clone, presenting as one of the two community-acquired infections, was identified. The presence of staphylococcal chromosomal cassette type IV and the Panton-Valentine leukocidin toxin gene were confirmed by PCR. This strain was not associated with necrotizing pneumonia, or severe skin or soft tissue infection.

\section{DISCUSSION}

The present retrospective cohort study provides data on the epidemiology, antimicrobial susceptibility patterns, molecular characteristics and outcomes of MRSA infection in our adult 
general systems ICU over a nine-year period. It is the first Canadian study of its kind and serves to emphasize the need for surveillance of antimicrobial-resistant organisms in our ICUs.

Infection rates from a large study of 38 German ICUs from 2001 to 2003 were comparable (22). Rates in American ICUs are substantially higher, with MRSA representing 55\% to 70\% of $S$ aureus isolates $(23,24)$. One Canadian study (25) found the mean MRSA rate reported from a survey of infection control programs in Canadian acute care hospitals in 2005 to be 2.0 per 1000 admissions. This is slightly lower than our reported rate of 3.1 per 1000 ICU admissions; however, this is expected because both ICU and non-ICU patients were included in the former study.

Fifty-eight per cent of infections were acquired within our institution, and although this is a substantial percentage, it represents only 21 cases of nosocomial infection over a nine-year period. Only 10 infections were unit acquired. This low rate of nosocomial transmission is, we hope, a result of strict infection control surveillance and isolation procedures at our institution.

The respiratory tract was the most common site of MRSA infection in our patients and has been similarly demonstrated to be a major site of infection in other studies (26-28).

Both animal and human studies have demonstrated improved survival with early, effective antimicrobial therapy in sepsis (29-31). Delays in initiation of effective therapy in our patients is concerning and may account for at least some portion of the high crude mortality observed.

Molecular characterization demonstrated that $59 \%$ of the strains acquired within our institution were identified as CMRSA-2. CMRSA-2 has been previously described as a hospital epidemic clone, which is consistent with our epidemiological

\section{REFERENCES}

1. Seal JB, Moreira B, Bethel CD, Daum RS. Antimicrobial resistance in Staphylococcus aureus at the University of Chicago Hospitals: A 15-year longitudinal assessment in a large university-based hospital. Infect Control Hosp Epidemiol 2003;24:403-8.

2. Diekema DJ, Pfaller MA, Schmitz FJ, et al; SENTRY Partcipants Group. Survey of infections due to Staphylococcus species: Frequency of occurrence and antimicrobial susceptibility of isolates collected in the United States, Canada, Latin America, Europe, and the Western Pacific region for the SENTRY Antimicrobial Surveillance Program, 1997-1999. Clin Infect Dis 2001;32(Suppl 2):S114-32.

3. Vincent JL, Bihari DJ, Suter PM, et al. The prevalence of nosocomial infection in intensive care units in Europe. Results of the European Prevalence of Infection in Intensive Care (EPIC) Study. EPIC International Advisory Committee. JAMA 1995;274:639-44.

4. National Nosocomial Infections Surveillance (NNIS) System Report, Data Summary from January 1992-June 2001, issued August 2001. Am J Infect Control 2001;29:404-21.

5. Berthelot P, Grattard F, Fascia P, et al. Implication of a healthcare worker with chronic skin disease in the transmission of an epidemic strain of methicillin-resistant Staphylococcus aureus in a pediatric intensive care unit. Infect Control Hosp Epidemiol 2003;24:299-300.

6. Gastmeier P, Sohr D, Geffers C, Nassauer A, Dettenkofer M, Ruden H. Occurrence of methicillin-resistant Staphylococcus aureus infections in German intensive care units. Infection 2002;30:198-202.

7. Saiman L, Cronquist A, Wu F, et al. An outbreak of methicillinresistant Staphylococcus aureus in a neonatal intensive care unit. Infect Control Hosp Epidemiol 2003;24:317-21.

8. Cosgrove SE, Qi Y, Kaye KS, Harbarth S, Karchmer AW, Carmeli Y. The impact of methicillin resistance in Staphylococcus aureus bacteremia on patient outcomes: Mortality, length of stay, and hospital charges. Infect Control Hosp Epidemiol 2005;26:166-74. data. Recent data suggest that CA-MRSA is becoming more prevalent and may soon replace hospital-acquired strains $(32,33)$. We did not observe a shift in our unit, with only two cases of community-acquired infection over the nine-year period. One of the two community-acquired infections was due to the CMRSA-10 clone. This confirms the emergence of CA-MRSA in our region, although it has yet to become a major pathogen in our ICU.

The limitations of our study include the single-centre design and the small number of infected patients (interquartile and subset analyses were not possible). Patients infected with MRSA in the ICU but not detected until after transfer to the ward would also have been missed, underestimating the rate of ICU-acquired MRSA infection. Also, the majority of our patients were not routinely screened on admission to the unit; therefore, the number of colonized patients in the study may not accurately reflect the rates of carriage. Lastly, vancomycin trough levels were not available, which, if subtherapeutic, may have had an effect on crude mortality rates.

\section{CONCLUSION}

MRSA infection was uncommon in our general systems ICU, with only 36 cases identified over nine years, but it was associated with a high crude mortality rate. ICU-acquired infection was even less common, with only 10 cases noted in the nine-year period. The majority of strains acquired in our institution were identified as CMRSA-2, indicating that this clone circulates in our institution. Delays in instituting effective antimicrobial therapy were observed, likely as a consequence of the low prevalence of MRSA in our patient population.

9. Niederman MS. Impact of antibiotic resistance on clinical outcomes and the cost of care. Crit Care Med 2001;29(Suppl 4):N114-20.

10. Shorr AF, Combes A, Kollef MH, Chastre J. Methicillin-resistant Staphylococcus aureus prolongs intensive care unit stay in ventilatorassociated pneumonia, despite initially appropriate antibiotic therapy. Crit Care Med 2006;34:700-6.

11. Miller LG, Perdreau-Remington F, Rieg G, et al. Necrotizing fasciitis caused by community-associated methicillin-resistant Staphylococcus aureus in Los Angeles. N Engl J Med 2005;352:1445-53.

12. Boussaud V, Parrot A, Mayaud C, et al. Life-threatening hemoptysis in adults with community-acquired pneumonia due to PantonValentine leukocidin-secreting Staphylococcus aureus. Intensive Care Med 2003;29:1840-3.

13. van der Flier M, van Dijk NB, Fluit AC, Fleer A, Wolfs TF, van Gestel JP. [Fatal pneumonia in an adolescent due to community-acquired methicillin-resistant Staphylococcus aureus positive for Panton-Valentine-leukocidin]. Ned Tijdschr Geneeskd 2003;147:1076-9.

14. Garner JS, Jarvis WR, Emori TG, Horan TC, Hughes JM. CDC definitions for nosocomial infections. Am J Infect Control 1988;16:128-40. (Erratum in 1988;16:177).

15. Performance Standards for Antimicrobial Susceptibility Testing: Seventeen Informational Supplement. Clinical and Laboratory Standards Institute. M100-S17. 2007;27(1).

16. Mulvey MR, Chui L, Ismail J, et al; Canadian Committee for the Standardization of Molecular Methods. Development of a Canadian standardized protocol for subtyping methicillin-resistant Staphylococcus aureus using pulsed-field gel electrophoresis. J Clin Microbiol 2001;39:3481-5.

17. Tenover FC, Arbeit RD, Goering RV, et al. Interpreting chromosomal DNA restriction patterns produced by pulsed-field gel electrophoresis: Criteria for bacterial strain typing. J Clin Microbiol 1995;33:2233-9.

18. Simor AE, Ofner-Agostini M, Bryce E, McGeer A, Paton S, Mulvey MR; Canadian Hospital Epidemiology Committee and 
Canadian Nosocomial Infection Surveillance Program, Health Canada. Laboratory characterization of methicillin-resistant Staphylococcus aureus in Canadian hospitals: Results of 5 years of National Surveillance, 1995-1999. J Infect Dis 2002;186:652-60.

19. Roberts RB, Tennenberg AM, Eisner W, et al. Outbreak in a New York City teaching hospital burn center caused by the Iberian epidemic clone of MRSA. Microb Drug Resist $1998 ; 4: 175-83$

20. Murchan S, Kaufmann ME, Deplano A, et al. Harmonization of pulsed-field gel electrophoresis protocols for epidemiological typing of strains of methicillin-resistant Staphylococcus aureus: A single approach developed by consensus in 10 European laboratories and its application for tracing the spread of related strains. J Clin Microbiol 2003;41:1574-85.

21. McDougal LK, Steward CD, Killgore GE, Chaitram JM, McAllister SK, Tenover FC. Pulsed-field gel electrophoresis typing of oxacillin-resistant Staphylococcus aureus isolates from the United States: Establishing a national database. J Clin Microbiol 2003;41:5113-20.

22. Meyer E, Schwab F, Gastmeier P, Jonas D, Rueden H, Daschner FD. Methicillin-resistant Staphylococcus aureus in German intensive care units during 2000-2003: Data from Project SARI (Surveillance of Antimicrobial Use and Antimicrobial Resistance in Intensive Care Units). Infect Control Hosp Epidemiol 2006;27:146-54.

23. Styers D, Sheehan DJ, Hogan P, Sahm DF. Laboratory-based surveillance of current antimicrobial resistance patterns and trends among Staphylococcus aureus: 2005 status in the United States. Ann Clin Microbiol Antimicrob 2006;5:2.

24. DeRyke CA, Lodise TP Jr, Rybak MJ, McKinnon PS. Epidemiology, treatment, and outcomes of nosocomial bacteremic Staphylococcus aureus pneumonia. Chest 2005;128:1414-22.
25. Zoutman DE, Ford BD. The relationship between hospital infection surveillance and control activities and antibiotic-resistant pathogen rates. Am J Infect Control 2005;33:1-5.

26. Montesinos I, Salido E, Delgado T, Lecuona M, Sierra A. Epidemiology of methicillin-resistant Staphylococcus aureus at a university hospital in the Canary Islands. Infect Control Hosp Epidemiol 2003;24:667-72.

27. Theaker C, Ormond-Walshe S, Azadian B, Soni N. MRSA in the critically ill. J Hosp Infect 2001;48:98-102.

28. Ibelings MM, Bruining HA. Methicillin-resistant Staphylococcus aureus: Acquisition and risk of death in patients in the intensive care unit. Eur J Surg 1998;164:411-8.

29. Kumar A, Roberts D, Wood KE, et al. Duration of hypotension before initiation of effective antimicrobial therapy is the critical determinant of survival in human septic shock. Crit Care Med 2006;34:1589-96.

30. Kumar A, Haery C, Paladugu B, et al. The duration of hypotension before the initiation of antibiotic treatment is a critical determinant of survival in a murine model of Escherichia coli septic shock: Association with serum lactate and inflammatory cytokine levels. J Infect Dis 2006;193:251-8.

31. Kollef MH, Ward S, Sherman G, et al. Inadequate treatment of nosocomial infections is associated with certain empiric antibiotic choices. Crit Care Med 2000;28:3456-64.

32. King MD, Humphrey BJ, Wang YF, Kourbatova EV, Ray SM, Blumberg HM. Emergence of community-acquired methicillinresistant Staphylococcus aureus USA 300 clone as the predominant cause of skin and soft-tissue infections. Ann Intern Med 2006;144:309-17.

33. Gosbell IB. Epidemiology, clinical features and management of infections due to community methicillin-resistant Staphylococcus aureus (cMRSA). Intern Med J 2005;35(Suppl 2):S120-35. 


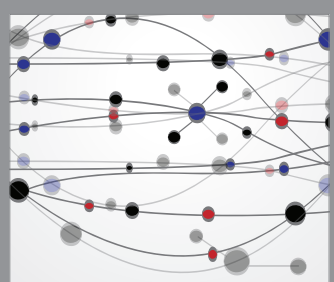

The Scientific World Journal
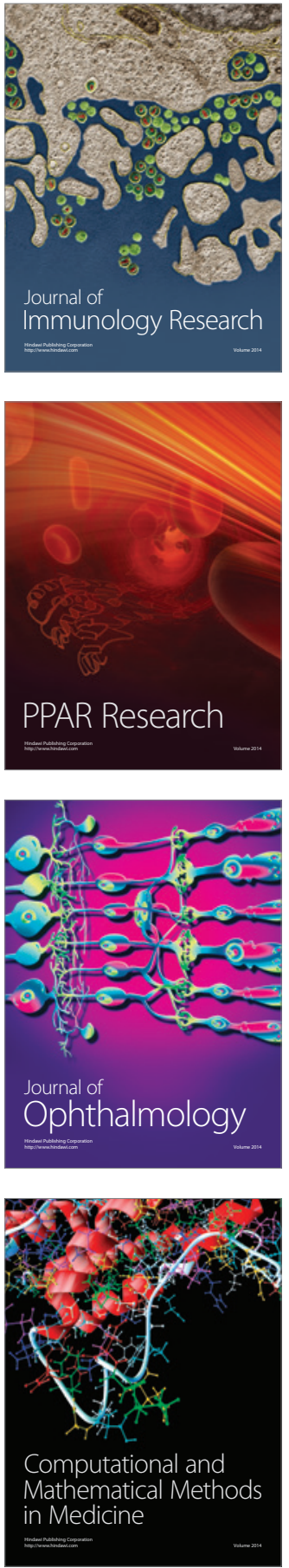

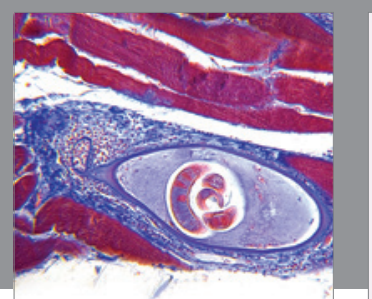

Gastroenterology Research and Practice

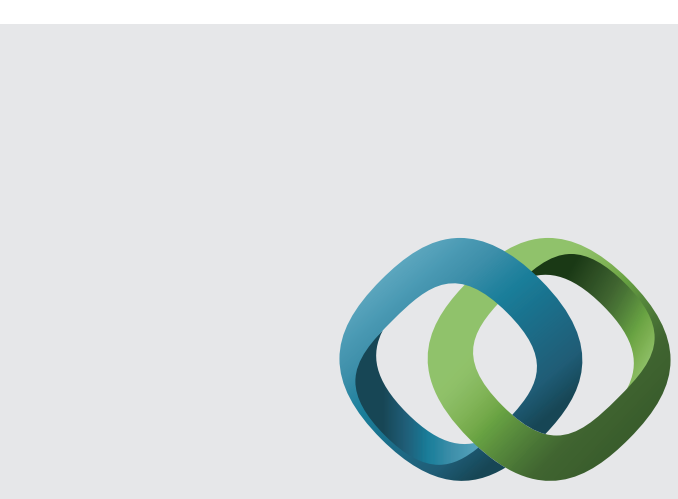

\section{Hindawi}

Submit your manuscripts at

http://www.hindawi.com
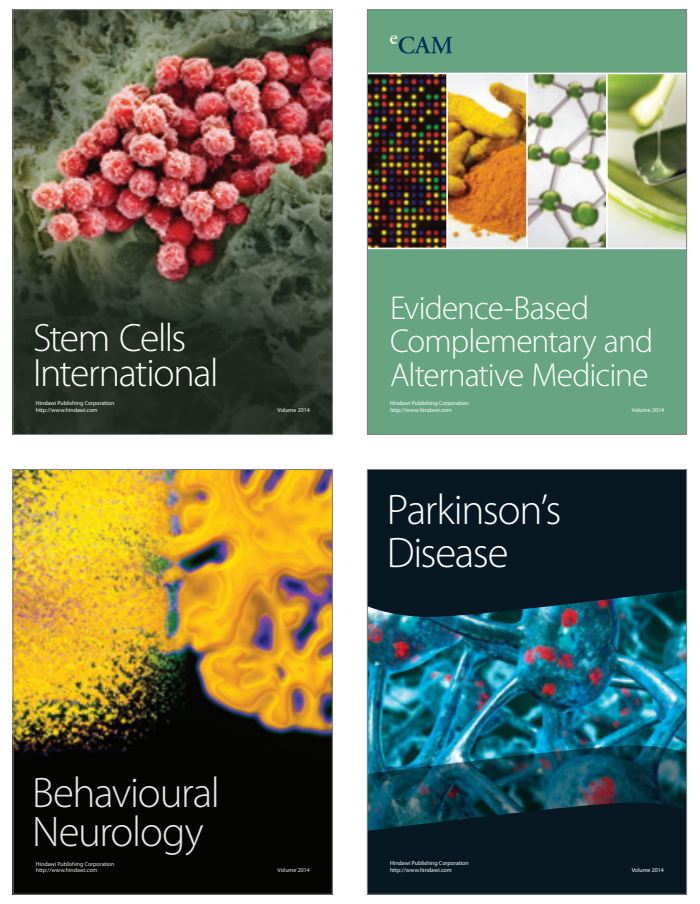
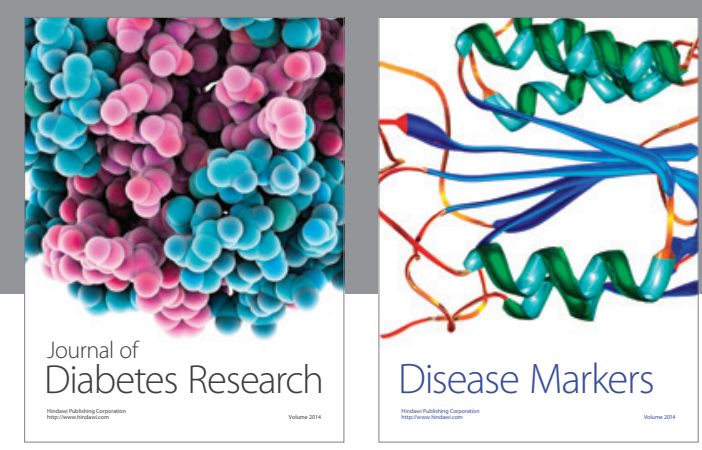

Disease Markers
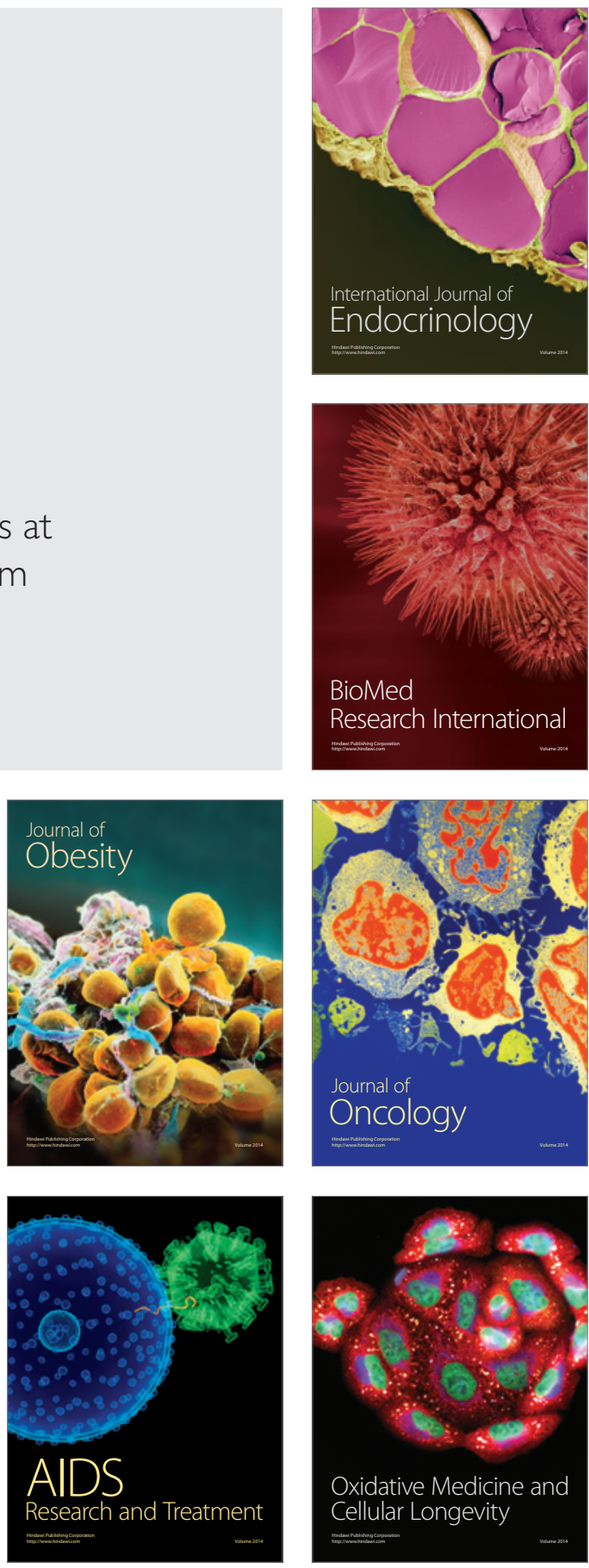